\title{
31. ACCUMULATION RATES OF MISSISSIPPI FAN SEDIMENTS CORED DURING DEEP SEA DRILLING PROJECT LEG 961
}

\author{
Andreas Wetzel, Geologisch-Paläontologisches Institut der Universität Tübingen \\ and \\ Barry Kohl, Chevron U.S.A., Inc. ${ }^{2}$
}

\begin{abstract}
Sediment accumulation rates $\left(\mathrm{g} / \mathrm{cm}^{2} \cdot 10^{3} \mathrm{yr}\right.$.) were calculated for undisturbed cores from the Mississippi Fan drill sites. These values take into account the effect of compaction, thus allowing an exact comparison between all sites and stratigraphic zones.

In the uppermost stratigraphic Zone $\mathrm{Z}$ of Ericson and Wollin, sediment accumulation is comparable to that found in hemipelagic sequences $\left(1-10 \mathrm{~g} / \mathrm{cm}^{2} \cdot 10^{3} \mathrm{yr}\right.$.). In Zone $\mathrm{Y}$ (late Wisconsin glacial), which spans a period of fluctuating sea level, the accumulation rates are one to three orders of magnitude greater than in Zone Z, using seismic Horizon 30 as the base of Ericson Zone Y. The largest amount of sediment accumulated in the axial area of the middle fan $(\sim 1,500$ $\mathrm{g} / \mathrm{cm}^{2} \cdot 10^{3} \mathrm{yr}$.), decreasing toward the flanks $\left(\sim 850 \mathrm{~g} / \mathrm{cm}^{2} \cdot 10^{3} \mathrm{yr}\right.$.) and downfan. In the lower fan area, accumulation rates of about $950 \mathrm{~g} / \mathrm{cm}^{2} \cdot 10^{3} \mathrm{yr}$. were determined. The accumulation rates of the Ericson Zone X (late Wisconsin interglacial), determined only at lower fan Site 615 , are intermediate $\left(\sim 100 \mathrm{~g} / \mathrm{cm}^{2} \cdot 10^{3}\right.$ yr.), but this value is influenced by debris flow deposits occurring in Zone $\mathrm{X}$.
\end{abstract}

\section{INTRODUCTION}

In the geological literature, the time-dependent process of sedimentation is often described by sedimentation rates, which are defined as unit sediment thickness per unit time. The use of sedimentation rates is very common, but they are only semiquantitative values because they are influenced by the state of sediment compaction. For example (Fig. 1), a thick pelitic sequence deposited under steady-state conditions can be described by a straight line with respect to the time-dependent sediment deposition process. When calculating sedimentation rates for individual intervals of such a sequence and plotting those versus depth, a stepped shape is obtained. This is the result of an increase in overburden pressure and therefore the amount of compaction with depth. Hence, the original relationship between sediment thickness and time becomes distorted. This is the reason why comparisons between sedimentation rates are inaccurate if the sediments have different actual as well as initial porosities, for instance, in comparing modern muds with highly compacted mudrocks. It is difficult, however, to correct sedimentation rates for compaction because initial porosities can vary within a wide range; hence, they cannot be exactly estimated for compacted sediments (Rieke and Chilingarian, 1974). Nonetheless, the inaccuracies of calculated sedimentation rates resulting from the varied porosities of deposits can be avoided by converting sedimentation rates to accumulation rates. Accumulation rates express the mass of sediment particles deposited per unit area during a certain time span (Koczy, 1951;

\footnotetext{
1 Bouma, A. H., Coleman, J. M., Meyer, A. W., et al., Init. Repts. DSDP, 96: Washing ton (U.S. Govt. Printing Office).

2 Addresses: (Wetzel) Geologisch-Paläontologisches Institut der Universität Tübingen, Sigwartstraße 10, D 7400 Tübingen, Federal Republic of Germany; (Kohl) Chevron U.S.A., Inc., 935 Gravier Street, New Orleans, LA 70112.
}

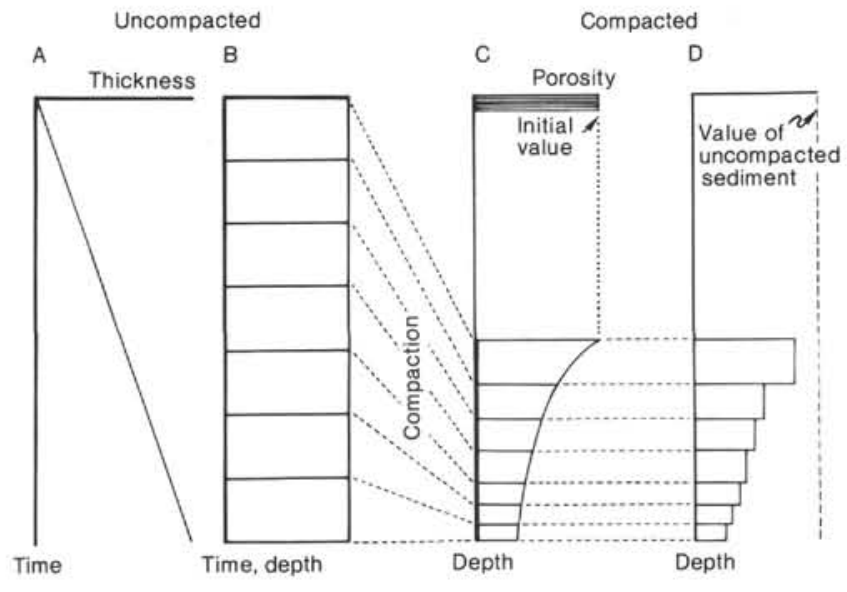

Figure 1. Influence of compaction on the calculation of sedimentation rates. (A) Time buildup diagram for a sequence with a constant amount of sediment deposition per unit time. (B) Uncompacted sedimentation rates (cm/unit time) of the sequence shown in (A). Because there exists a linear relationship between depth and time, these parameters are equivalent to each other. (C) Effect of compaction on the porosity of a sequence that was deposited as shown in (A). (D) Sedimentation rates calculated for the compacted sequence with the same time intervals as shown in (B). The sedimentation rates are also influenced by compaction and decrease downhole.

van Andel et al., 1975). This method has the advantage that all values can be easily compared.

It is the purpose of this chapter to calculate accumulation rates for eight sites on the Mississippi Fan, because considerable downhole changes in porosity as well as varying sediment composition (see site chapters, this volume) do not allow an accurate comparison of sedimentation rates between these sites. The sites are located in the middle and lower fan areas (Fig. 2).

A transect of sites was drilled across the middle fan from channel to overbank deposits. Sites 621 and 622 


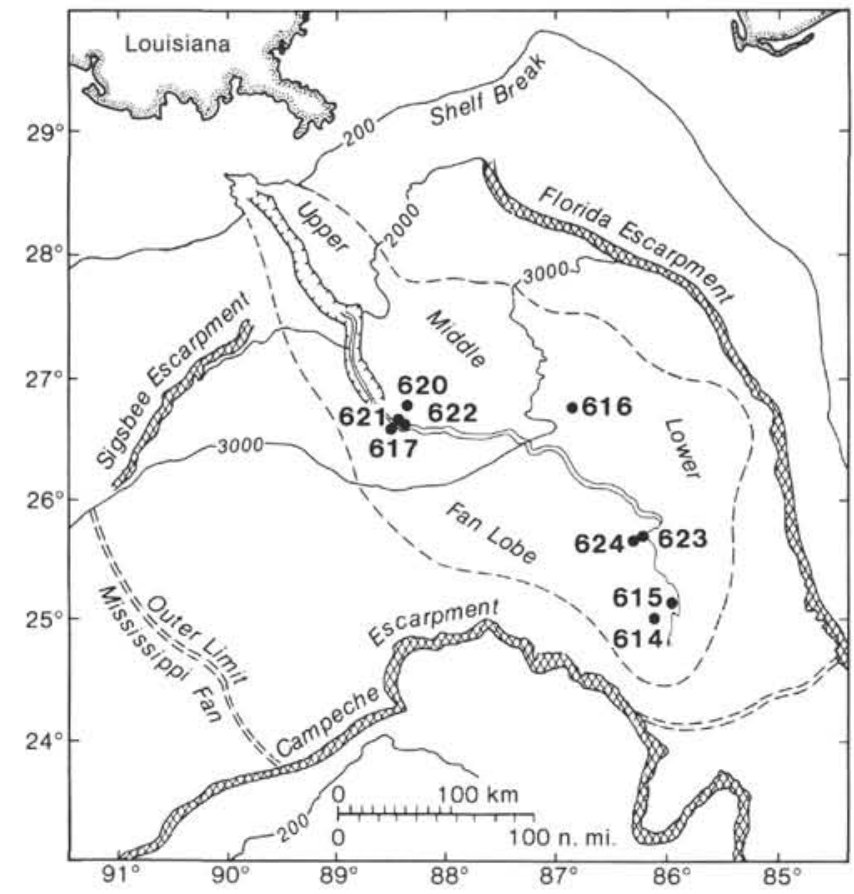

Figure 2. Location of sites discussed.

are situated in the central channel. Holes at both sites were drilled to sub-bottom depths of about $200 \mathrm{~m}$. The cored channel-fill sequences show overall fining-upward trends from gravel through alternating sands, silts, and thinly bedded muds into thickly bedded muds.

Hole 617 was drilled to $191 \mathrm{~m}$ sub-bottom depth in a swale on the western side of the channel. Three units capped by a thin foraminiferal mud were penetrated: (1) a lower 108-m-thick coarsening-upward sequence composed primarily of mud, (2) a 38-m-thick uniform siltlaminated mud, and (3) an uppermost fining-upward sequence consisting of mud with some silt laminae.

Hole 620 penetrated $423 \mathrm{~m}$ of overbank deposits and is located $18.3 \mathrm{~km}$ away from the central channel on the middle fan.

Hole 616 was drilled in the overbank region $55 \mathrm{~km}$ away from the central channel. The 371-m-deep hole penetrated, from bottom to top: (1) a lower mud unit (110 $\mathrm{m}$ thick), (2) sand-rich material (110 m thick), (3) a siltlaminated mud sequence ( $88 \mathrm{~m}$ thick), and (4) a slightly coarsening-upward silt-laminated mud sequence $(63 \mathrm{~m}$ thick). The upper $95 \mathrm{~m}$ of this sediment section are slumped deposits.

In the lower fan, four sites were visited (Fig. 2). Sites 623 and 624 are on the margin of the lower fan channel, and holes were drilled to depths of $\sim 200 \mathrm{~m}$ sub-bottom. Sediments at both sites consist of alternating 10- to 20$\mathrm{m}$-thick channel-fill deposits (fining-upward sequences rich in sand) and 20- to 60 -m-thick overbank deposits (poorly defined coarsening-upward sequences).

Hole 615 was drilled to $523 \mathrm{~m}$ sub-bottom depth. The youngest fan lobe is $199 \mathrm{~m}$ thick; the underlying fan lobe is $283 \mathrm{~m}$ thick. The base of the latter is marked by seismic Horizon 30, which could be correlated with the stratigraphic boundary between Zones $\mathrm{X}$ and $\mathrm{Y}$ of Eric- son and Wollin (1968). The late Wisconsin interstadial (Zone X) consists of a fine-grained carbonate sequence probably derived from the western part of the Florida platform (Brooks et al., this volume). The sedimentary structures suggest that it was deposited by a debris flow.

Site 614 was drilled to a sub-bottom depth of about $150 \mathrm{~m}$. The composition of the drilled section is similar to that of Site 615 .

In general, Holocene sediments form only a thin cover of several decimeters. In contrast, the late Wisconsin sediments are turbidites ranging from several tens to several hundred meters in thickness.

On Leg 96, only the middle and lower fan regions were drilled. Because of safety reasons, no data for the upper fan deposits are available.

\section{ACCUMULATION RATES OF MISSISSIPPI FAN DEPOSITS}

\section{Stratigraphic Framework}

Accumulation rates were calculated for three distinct, major stratigraphic intervals found in the Mississippi Fan sites: the Z, Y, and X zones of Ericson and Wollin (1968) for the late Quaternary period (see site chapters and Explanatory Notes, this volume). The $\mathrm{Z} / \mathrm{Y}$ boundary is dated at $12,000 \mathrm{yr}$. ago, the $\mathrm{Y} / \mathrm{X}$ boundary at $85,000 \mathrm{yr}$. ago, and Zone $\mathrm{X}$ began 127,000 yr. ago.

The sub-bottom depths of these stratigraphic boundaries at each of the Leg 96 Mississippi Fan drill sites (except Site 620) are given in Table 1. Because the Y/X stratigraphic boundary was penetrated only at Site 615 , the sub-bottom depth of this boundary at the other sites was estimated by interpolation to the depth of seismic Horizon 30 (see Introduction and site chapters, this volume). The depth of seismic Horizon 30 coincides with the Y/X boundary at Site 615 as well as in other drill holes and soil foundation borings along the rim of the present Mississippi Fan (Coleman et al., in press), indi-

Table 1. Sub-bottom depth (m) of stratigraphic boundaries according to the zonation of Ericson and Wollin (1968).

\begin{tabular}{ccccc}
\hline Site & $\mathrm{Z} / \mathrm{Y}^{\mathrm{a}}$ & $\mathrm{Y} / \mathrm{X}^{\mathrm{b}}$ & $\mathrm{Y} / \mathrm{X}^{\mathrm{a}}$ & $\mathrm{X} / \mathrm{W}^{\mathrm{a}}$ \\
\hline 614 & 0.50 & 468 & & \\
615 & 0.50 & & $485^{\mathrm{c}}$ & $515^{\mathrm{c}}$ \\
616 & 0.25 & 505 & & \\
617 & 0.25 & 772 & & \\
621 & 1.50 & 781 & & \\
622 & 1.50 & 753 & & \\
623 & 0.25 & 537 & & \\
624 & 0.25 & 521 & & \\
\hline
\end{tabular}

${ }^{\text {a }}$ Stratigraphic boundaries of this interval were penetrated in the hole.

$b$ Based on estimated depth of $\mathrm{Y} / \mathrm{X}$ boundary placed at the depth of seismic Horizon 30. ${ }^{c}$ Drilled depths to Ericson Zone $\mathrm{Y} / \mathrm{X}$ and $\mathrm{X} /$ W boundaries were revised slightly after this paper was written, although the revised depths do not significantly affect accumulation rate calculations given here. See Site 615 chapter (this volume) for revised boundary depths. 
cating that this seismic horizon is useful as a stratigraphic marker.

\section{Calculation of Accumulation Rates}

Koczy (1951) calculated accumulation rates from sedimentation rates using the expression

$$
\alpha=\omega \cdot \rho_{\mathrm{d}}
$$

where $\alpha$ is accumulation rate in $\mathrm{g} / \mathrm{cm}^{2} \cdot 10^{3} \mathrm{yr}$., $\omega$ is sedimentation rate in $\mathrm{cm} / 10^{3}$ yr. and $\rho_{\mathrm{d}}$ is dry bulk density in $\mathrm{g} / \mathrm{cm}^{3}$. Using wet-bulk density and porosity data determined on board by the cylinder technique and the gamma ray attenuation porosity evaluator (GRAPE) method (see Explanatory Notes and site chapters, this volume) as well as information from well logs (see site chapters, this volume), dry-bulk density $\left(\rho_{\mathrm{d}}\right)$ can be calculated with the equation

$$
\rho_{\mathrm{d}}=\rho_{\mathrm{w}}-1.026 n_{\mathrm{f}}
$$

where $\rho_{\mathrm{w}}$ is wet-bulk density, $n_{\mathrm{f}}$ is fractional porosity, and 1.026 equals the density of seawater. The values of dry-bulk density and interpolated values for unsampled sections have been summed over depth. In this way, a curve representing depth versus the cumulative mass of dry sediment has been obtained for each site (Fig. 3). Each curve is based on 100-500 determinations. These procedures were applied to all of the Mississippi Fan sites

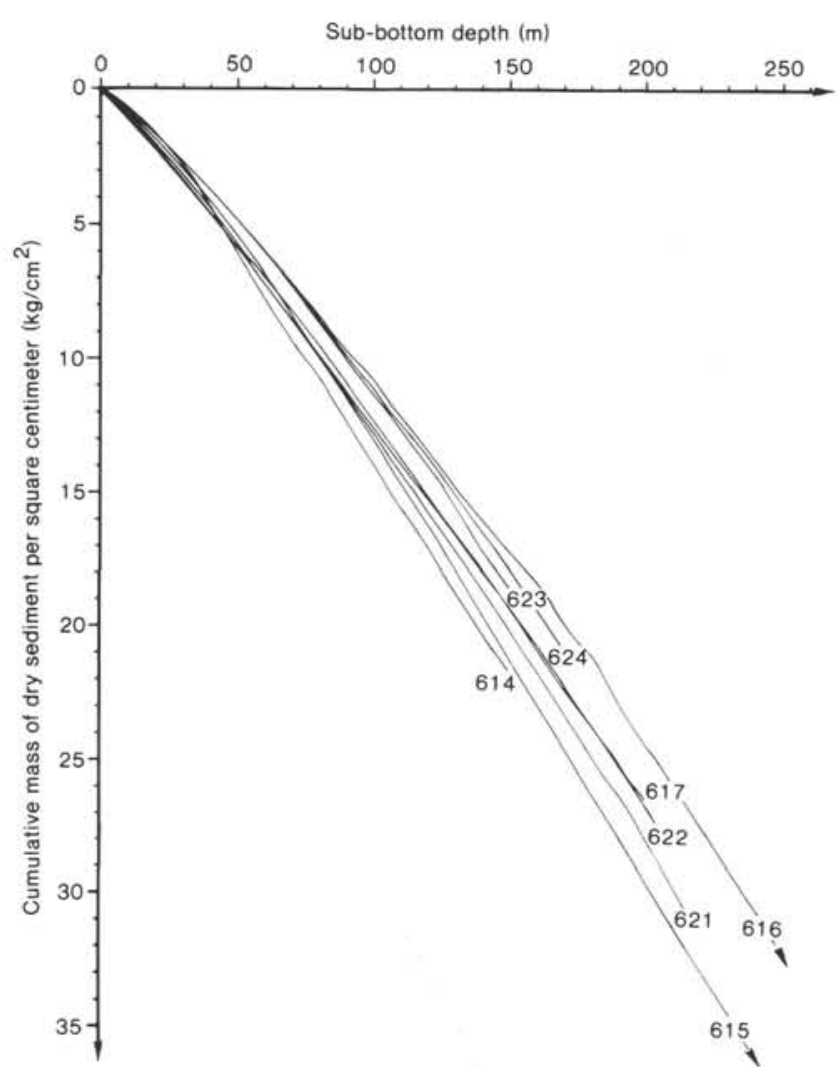

Figure 3. Relationship between sub-bottom depth and cumulative mass of dry sediment per square centimeter. Each line is based on 100 to 500 determinations at each site. except for Site 620 because of its high degree of drilling disturbance (see site chapters, this volume).

For the calculation of accumulation rates, the cumulative mass of sedimentary particles was also interpolated to the depth of seismic Horizon 30. Accumulation rates for stratigraphic Zones Z, Y, and X at Leg 96 Mississippi Fan sites are listed in Table 2 and shown in Figure 4.

\section{Accuracy of Calculated Rates}

The calculations are subject to a certain amount of error which stems primarily from three factors: (1) inexact stratigraphic determinations, (2) inaccurate determinations or estimations of porosity and wet-bulk density, and (3) interpolation to a seismic stratigraphic boundary. Because the relevance of each factor is different for each of the stratigraphic intervals, the errors in calculation for Zones $\mathrm{Z}$ and $\mathrm{Y}$ will be discussed separately.

\section{Zone $\mathbf{Z}$}

1. Inaccuracies due to sampling intervals and the transformation to absolute ages may lead to an error of about $5 \%$.

2. Because of densely spaced sampling, errors due to porosity/wet-bulk density evaluation are about $1 \%$ in the range of the applied methods (see Explanatory Notes, this volume).

3 . The possibility of incomplete recovery of the recent seafloor sediment may contribute the largest error to the calculations. It may be $50 \%$ or more.

\section{Zone Y}

1. Inexact biostratigraphic dating may create an error of about $1 \%$ when considering the total time span of this zone.

2. The evaluation of porosity/wet-bulk density and the interpolation for unsampled intervals may lead to an inaccuracy of 2 to $5 \%$ in calculations when well logs are the basis for such evaluations.

Table 2. Sediment accumulation rates of Mississippi Fan deposits

\begin{tabular}{|c|c|c|c|c|}
\hline Site & $\mathrm{z}^{\mathrm{a}}$ & $\mathrm{Y}^{\mathrm{b}}$ & $\mathrm{Y}^{\mathrm{a}}$ & $x^{a}$ \\
\hline $\begin{array}{l}614 \\
615 \\
616 \\
617 \\
621 \\
622 \\
623 \\
624\end{array}$ & $\begin{array}{r}2.9 \\
3.0 \\
1.5 \\
1.8 \\
11.7 \\
12.8 \\
1.5 \\
1.4\end{array}$ & $\begin{array}{c}894.8 \\
842.7^{c} \\
1393.6 \\
1571.0 \\
1511.8 \\
1044.1 \\
1023.2\end{array}$ & 949.5 & $37.0^{\mathrm{d}}$ \\
\hline \multicolumn{5}{|c|}{$\begin{array}{l}\text { a Stratigraphic boundaries of this inter- } \\
\text { val were penetrated in the hole. } \\
\text { b Based on estimated depth of } \mathrm{Y} / \mathrm{X} \\
\text { boundary placed at the depth of seis- } \\
\text { mic Horizon } 30 \text {. } \\
\text { c Slumped sediment }(0.25-100 \mathrm{~m} \text { sub- } \\
\text { bottom) has been excluded from the } \\
\text { calculation of accumulation rates. } \\
\text { Based on the assumption that } 2 / 3 \text { of } \\
\text { the sediment mass belongs to a grain } \\
\text { flow deposit that has been excluded } \\
\text { from the calculation of the accumula- } \\
\text { tion rate. }\end{array}$} \\
\hline
\end{tabular}
$\left(\mathrm{g} / \mathrm{cm}^{2} \cdot 10^{3} \mathrm{yr}.\right)$. 


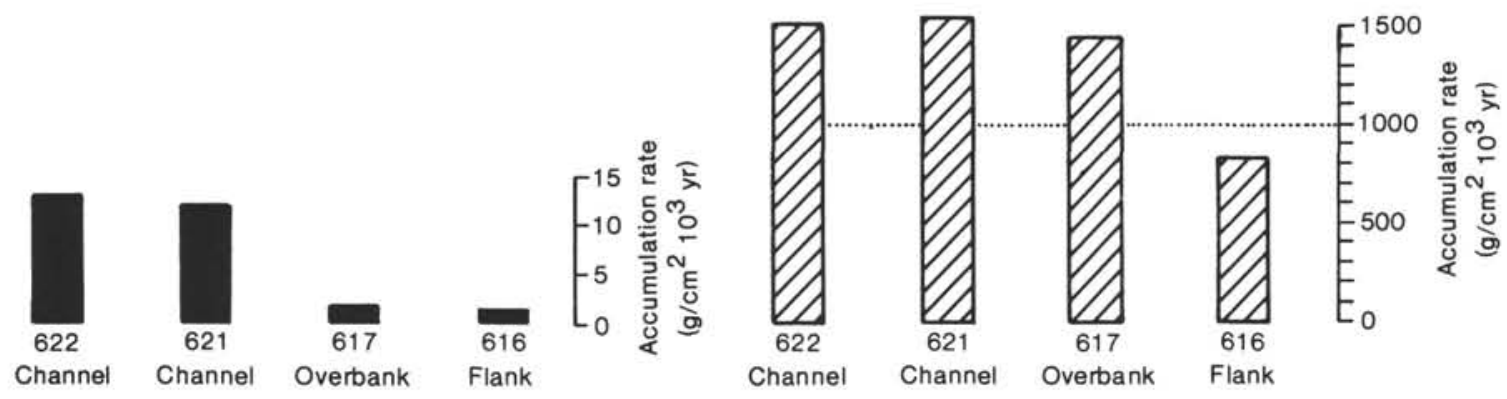

Lower Fan

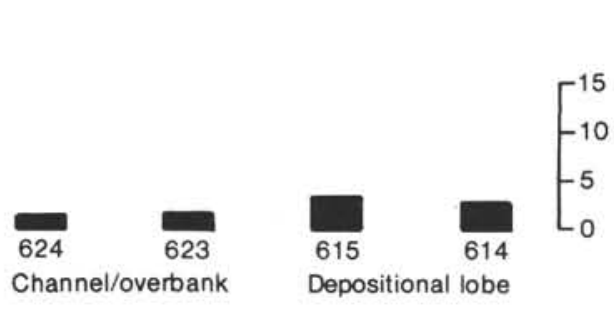

Zone Z

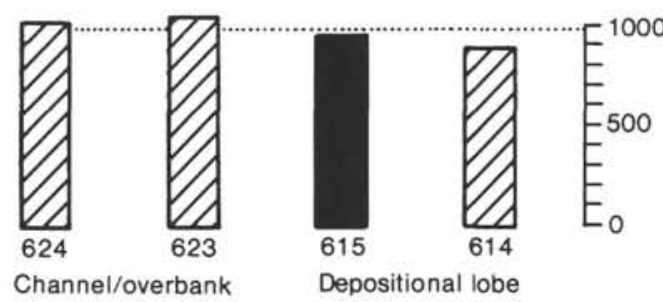

Zone $Y$

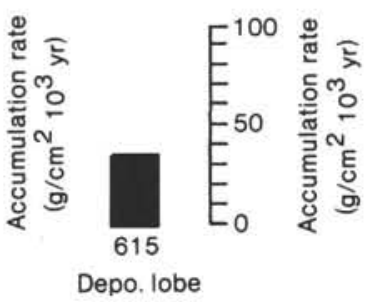

Zone X

Figure 4. Graphic representation of accumulation rates. Note the difference in scale between Zone Z, Y, and X deposits. Estimation of sub-bottom depth of the stratigraphic boundaries influences calculations. Solid bars refer to the penetrated stratigraphic boundary and cross-hatched bars indicate the interpolated stratigraphic boundary at the depth of seismic Horizon 30.

3. Interpolations down to seismic Horizon 30 can produce the largest error in the calculation of the accumulation rates for this zone. However, because this zone contains two fan lobes similar in structure, it is likely that the error due to interpolation is relatively small when the trends found in the upper fan lobe are interpolated down to seismic Horizon 30. This was proven in the Site 615 sediments, where such an interpolation leads to an error of less than $5 \%$.

Therefore, it can be concluded that all errors together would be less than $10 \%$ for Zone Y.

The possible inaccuracies in the calculation of accumulation rates are more or less relevant to the interpretation of these rates. (1) The sediment accumulation pattern of Zone $\mathrm{Z}$ deposits can totally result from incomplete sediment recovery. (2) The differences in sediment accumulation in Zones $\mathrm{Z}$ and $\mathrm{Y}$ are significantly larger than the sum of maximum errors for both zones. (3) The sediment accumulation rates of Zone $\mathrm{Y}$ deposits do not differ significantly for sites drilled close together $[(621,622,617),(616),(623,624)$, and $(614,615)]$, whereas the differences between these groups are larger than the possible inaccuracies.

\section{INTERPRETATION AND DISCUSSION OF ACCUMULATION RATE DATA}

The data within their range of confidence allow an interpretation of the general pattern of deposition. Two aspects will be discussed here: (1) the implications of sea level fluctuations on sediment accumulation in the fan and (2) the spatial pattern of sediment deposition.

\section{Implications of Sea Level Fluctuations}

Sediment accumulation is low during times of rising or high sea level (Zones $\mathrm{Z}$ and $\mathrm{X}$ ). These deposits contain only a minor proportion of turbidites (see site chapters, this volume). The accumulation rates reach several $10 \mathrm{~g} / \mathrm{cm}^{2} \cdot 10^{3} \mathrm{yr}$. This is similar to rates calculated for other near-continent, turbidite-free, deep-sea hemipelagic deposits (Ehrmann and Thiede, 1985). During times of falling or low sea level (Zone Y) the sediment accumulation is two to three orders of magnitude higher than during the Zone $\mathrm{Z}$ period. The $\mathrm{Y}$ section predominantly contains turbidites (see site chapters, this volume).

Thus, sediment accumulation in the Mississippi Fan area primarily depends on turbidite frequency. This fits the well-known fact that turbidite frequency is related to relative changes of sea level (e.g., Shanmugam and Moiola, 1981). For siliciclastic, fine-grained deposits seaward of deltas, this phenomenon can be explained as follows: During high sea level the major proportion of river-transported material is trapped on the shelf, and mass movement processes down to the deep sea are not very frequent. During falling sea level, slope instability increases because of the development of overpressure in finegrained sediments (e.g., Morgenstern, 1967). The frequency of mass movements thereby increases, as it did in the case of Mississippi Delta front (e.g., Coleman et al., in press). Furthermore, the estuary moves seaward and a large amount of sediment is carried to the continental slope or to the canyon mouth, producing a higher sediment delivery to the deep sea (Stow et al., 1983/84). 
This is also the case during low stands of sea level. Rising sea level has the inverse effect of falling sea level: The estuary moves back to the continent and a large amount of sediment is trapped on the shelf, thus sediment accumulation decreases in the fan area (e.g., Nelson and Kulm, 1973).

\section{Spatial Pattern of Sediment Deposition}

Sea level changes affect the sediment accumulated in the Mississippi Fan and thus also the spatial pattern of sediment deposition. Therefore, Zone $\mathrm{Z}$ and $\mathrm{Y}$ deposits will be discussed separately.

\section{Zone $Z$ Deposits}

Sediment accumulation is highest at the midfan channel (Sites 621 and 622), decreasing with lateral distance from the channel (Sites 617 and 616) as well as downfan. There, sedimentation is higher at the depositional lobe (Sites 614 and 615) than at the overbank regions (Sites 623 and 624) (Table 2, Fig. 4).

The sediment accumulation pattern suggests that there still is a small sediment supply from the delta via the channel to the fan. It is likely that some suspended sediment is transported from just seaward of the delta into the canyon flowing into the channel. Most of the deposition occurs in the midfan channel and to a lesser degree at the end of the channel (Sites 614 and 615). The sediment supply to the overbank areas seems to be hindered by the greater relief in these areas. This pattern is in good agreement with the observations of Nelson and Kulm (1973) on the Astoria Fan in the northwestern Pacific Ocean.

\section{Zone Y Deposits}

During late Wisconsin glacial time, the largest amount of sediment was deposited in the axial part of the middle fan (Sites 621, 622, and 617). Sediment accumulation decreases with increasing distance from the channel axis (Site 616) as well as downfan at Sites 623 and 624 and finally at Sites 614 and 615 (Table 2, Fig. 4).

This pattern can be explained by the turbidity current origin of the deposits. As turbidity currents flow through the channel, a lot of material is brought into suspension at the head of the flow, forming a low-concentration "cloud" above it (Middleton and Hampton, 1973). This fine-grained suspension has lost most of the initial kinetic energy of the turbidity current due to turbulence (Middleton, 1970), and therefore, this suspension moves slowly laterally as well as downfan. In this way, thick overbank deposits and a well-developed channel are formed. Downfan this entire process continues, thus the turbidity flow is continuously enriched in sand that is ultimately deposited in the lower fan. It can be deduced from the accumulation rate data that turbidity currents have deposited most of their load in the middle fan area. This is supported by seismic investigations showing that the middle fan contains the largest sediment volume (Coleman et al., in press).

In the active channel only lag deposits may remain, because the deposited material may be eroded by succeeding turbidity currents. Seismic data suggest (see site chapters, this volume) that the channel is filled primarily after buildup of overbank deposits, but there is not an indication of this from the accumulation rate data. To answer this question, more detailed stratigraphy is necessary.

\section{CONCLUSIONS}

1. Calculation of accumulation rates accounts for the effects of compaction with burial depth. Therefore an exact comparison between different sedimentary sections is possible:

2. Accumulation rates were determined for the Holocene (Zone $\mathrm{Z}$ ) and late Wisconsin glacial (Zone Y) deposits of eight drill sites on the Mississippi Fan. Accumulation rates are related to the frequency of turbidites, which in turn depends on relative changes of sea level. During phases of rising or high sea level (Zone Z) turbidite frequency is low, and thus sediment accumulation rates are also low, ranging from 1 to $10 \mathrm{~g} / \mathrm{cm}^{2} \cdot 10^{3} \mathrm{yr}$. This is similar to the range reported from other hemipelagic near-continent deposits that contain only a minor proportion of turbidites. During falling or low sea level (Zone Y), sediment accumulation is two to three orders of magnitude higher than during the Zone $\mathrm{Z}$ period mainly because of frequent turbidite deposition.

3. The accumulation rate calculations for the Zone $Z$ deposits may be heavily influenced by incomplete recovery of modern seafloor sediments, whereas the determinations for the Zone $\mathrm{Y}$ deposits have inaccuracies of 5 to $10 \%$ only.

4. Sites located near one another show similar rates of sediment accumulation, but the differences between such groups exceed the possible errors of determinations for the Zone Y deposits.

5. For Zone $Y$ deposits, sites drilled in the axial part of the midfan region show the highest accumulation rates $\left(\sim 1500 \mathrm{~g} / \mathrm{cm}^{2} \cdot 10^{3} \mathrm{yr}\right.$.), decreasing laterally $(55 \mathrm{~km}$ away from the channel at Site 616: $850 \mathrm{~g} / \mathrm{cm}^{2} \cdot 10^{3} \mathrm{yr}$ ) as well as downfan (lower fan depositional lobe: $\sim 950 \mathrm{~g} / \mathrm{cm}^{2}$. $10^{3} \mathrm{yr}$.). This pattern can be interpreted in terms of the flow characteristics of turbidity currents that predominantly carry pelitic material: these flows lose the major proportion of their load in the middle fan as a result of turbulence at the head of the flow.

6 . The relationships between sea level changes and turbidite frequency as well as between turbidite depositional processes and sediment accumulation patterns are in good agreement with similar relationships described from other modern fans.

\section{REFERENCES}

Coleman, J. M., Bouma, A. H., Adams, C. E., and Prior, D. B., in press. Mississippi Canyon and deep-sea fan: seismic facies and depositional processes. Am. Assoc. Pet. Geol. Bull.

Ehrmann, W. U., and Thiede, J., 1985. History of Mesozoic and Cenozoic sediment fluxes to the north Atlantic ocean. Contrib. Sedimentol., 15:1-109.

Ericson, D. B., and Wollin, G., 1968. Pleistocene climates and chronology of deep-sea sediments. Science, 162:1227-1234.

Koczy, F. F., 1951. Factors determining the element concentration in sediments. Geochim. Cosmochim. Acta, 1:73-85.

Middleton, G. V., 1970. Experimental studies related to problems of flysch sedimentation. Geol. Assoc. Can. Spec. Pap., 7:253-272. 
Middleton, G. V., and Hampton, M. A., 1973. Sediment gravity flows: mechanics of flow and deposition. In Middleton, G. V., and Bouma, A. H. (Eds.), Turbidites and Deep Water Sedimentation. Soc. Econ. Paleontol. Mineral., Pacific Section Short Course, pp. 1-38.

Morgenstern, N. R., 1967. Submarine slumping and the initiation of turbidity currents. In Richards, A. F. (Ed.), Marine Geotechnique: Urbana (Univ. Illinois Press), pp. 189-220.

Nelson, C. H., and Kulm, V., 1973. Submarine fans and channels. In Middleton, G. V., and Bouma, A. H. (Eds.), Turbidites and Deep Water Sedimentation. Soc. Econ. Paleontol. Mineral., Pacific Section Short Course, pp. 39-78.

Rieke, H. H. III, and Chilingarian, G. V., 1974. Compaction of Argillaceous Sediments: Amsterdam (Elsevier).
Shanmugam, G., and Moiola, R. J., 1981. Eustatic control of turbidites and winnowed turbidites. Geology, 10: 231-235.

Stow, D. A. V., Howell, D. G., and Nelson, C. H., 1983/84. Sedimentary, tectonic and sea-level controls on submarine fan and slopeapron turbidite systems. Geo-Mar. Lett., 3:117-125.

van Andel, T. H., Heath, G. R., and Moore, T. C., 1975. Cenozoic history and paleoceanography of the central equatorial Pacific Ocean. Mem. Geol. Soc. Am., 143:1-134.

Date of Initial Receipt: 29 August 1984 Date of Acceptance: 30 July 1985 